\title{
Tatlockia and Fluoribacter: Two New Genera of Organisms Resembling Legionella pneumophila
}

\author{
G. M. GARRITY, ${ }^{1,2}$ A. BROWN, ${ }^{1,2}$ AND R. M. VICKERS ${ }^{1}$ \\ Medical, Laboratory, and General Medical Research Services, Veterans Administration Medical Center, \\ Pittsburgh, Pennsylvania 15240, ${ }^{1}$ and the School of Medicine and Graduate School of Public Health, \\ University of Pittsburgh, Pittsburgh, Pennsylvania 15261 ${ }^{2}$
}

\begin{abstract}
DNA homology studies were performed with strains of Legionella pneumophila Brenner et al., 1979, including the type strain, ATCC 33152, and a group of seven previously unclassified bacteria which resemble L. pneumophila in growth characteristics and colonial morphology and by their content of large amounts of branched-chain fatty acids. The organisms studied include three isolates of the Pittsburgh pneumonia agent (PPA), TATLOCK, WIGA (ALLO 1 ), MI-15 $\left(\mathrm{ALLO}_{2}\right)$, and NY-23 $\left(\mathrm{ALLO}_{4}\right)$. The purified DNAs were labeled with ${ }^{32} \mathrm{P}$ in vitro by a nick translation method, which made it possible to achieve very high specific activities. Results of our hybridization experiments suggest that these previously unclassified organisms are not related to L. pneumophila at the genus level, and thus two new genera within the family Legionellaceae are proposed for them: Tatlockia and Fluoribacter. The type species of these genera are T. micdadei (Hebert et al., 1980) comb. nov. and $F$. bozemanae sp. nov., respectively. The type strain of $T$. micdadei is strain TATLOCK (= ATCC 33218), and the type strain of $F$. bozemanae is strain WIGA (= ATCC 33217).
\end{abstract}

Legionnaires' disease, first recognized during an outbreak in Philadelphia in 1976 (9), has been shown to be due to infection with a bacterium (15) for which the name Legionella pneumophila has been proposed (5). This organism is gram negative and requires cysteine, iron salts, and a medium buffered at $\mathrm{pH} 6.9$ for optimal growth (8).

Since the isolation of $L$. pneumophila, intensive study of previously unclassified organisms $(1,10,16,24)$ and a search for new isolates $(7$, $12,14,21,25)$ from both human and environmental sources has led to the recognition of a number of organisms resembling L. pneumophila with respect to nutritional requirements and colonial morphology $(7,12,14)$. Of these organisms, L. pneumophila, WIGA (ALLO $)_{1}$, Pittsburgh pneumonia agent (PPA), HEBA, and TATLOCK possess common flagellar antigens $(10,12)$, a relationship which may exist among all flagellated members of this group of organisms and which may be of taxonomic importance. Cellular fatty acid analysis disclosed the presence of branched-chain fatty acids in unusually large amounts for gram-negative organisms (19), and characteristic fatty-acid patterns were described for L. pneumophila and for several others of these bacteria $(7,10,14,18,19)$.

In this article, we present extensive deoxyribonucleic acid (DNA)-DNA homology data in an attempt to determine the relatedness among members of this group. Since the original sub- mission of this manuscript for publication, two articles have appeared proposing scientific names for the organisms referred to as TATLOCK and PPA $(11,20)$; one of the articles also refers to the name $L$. bozemanii for the WIGA bacterium, but a formal proposal is not made (11). Both sets of authors have placed these organisms in the genus Legionella. Our data, as well as the available data presented in these other reports, do not support the classification of these organisms into a single genus, but argue strongly for the establishment of at least two new genera for these organisms.

\section{MATERIALS AND METHODS}

Bacterial strains. The strains of bacteria used in this study are listed in Table 1.

Media. Working stocks were maintained on buffered charcoal yeast extract (BCYE) agar (20). Media were buffered to $\mathrm{pH} 6.9\left(20^{\circ} \mathrm{C}\right)$ with $1 \%$ ACES [ $N$-(2 acetamido)-2-aminoethanesulfonic acid, (Research Organics, Inc., Cleveland, Ohio)]. Cultures for DNA extraction were prepared by making a suspension of agar-grown bacteria in buffered yeast extract broth (BYEB) (YEB) (prepared as described by Ristroph et al. [22] except that the charcoal adsorption step was omitted) with the turbidity adjusted to that of a number $5 \mathrm{McF}$ arland standard. A 2-ml amount of this suspension was then inoculated into $500 \mathrm{ml}$ of BYEB. Cultures were incubated for $24 \mathrm{~h}$ at $37^{\circ} \mathrm{C}$ with continuous shaking. Cells of Escherichia coli were similarly prepared.

Biochemical tests. Catalase and oxidase tests were performed by previously described techniques (26). 
TABLE 1. Strains used in this study

\begin{tabular}{|c|c|c|c|c|c|}
\hline $\begin{array}{l}\text { Laboratory } \\
\text { designation }\end{array}$ & Name & Strain & $\begin{array}{c}\text { Received } \\
\text { from }^{a}\end{array}$ & $\begin{array}{l}\text { Source of iso- } \\
\text { lation }\end{array}$ & Reference \\
\hline$\overline{\mathrm{LDB}^{b}} 1$ & L. pneumophila & Philadelphia 1 (= ATCC 33152$)$ & 1 & Human & 5 \\
\hline LDB 2 & L. pneumophila & Bellingham & 1 & Human & 5 \\
\hline LDB 3 & L. pneumophila & PER & 2 & Human & \\
\hline PPA 1 & Unclassified & $\mathrm{PPA} / \mathrm{EK}(=\mathrm{ATCC} 33204)$ & 3 & Human & \\
\hline PPA 2 & Unclassified & $\mathrm{PPA} / \mathrm{LR}$ & 3 & Human & \\
\hline PPA 3 & Unclassified & PPA/PGH-12 & 4 & $\begin{array}{l}\text { Environ- } \\
\text { mental }\end{array}$ & \\
\hline TAT & L. micdadei & TATLOCK (= ATCC 33218) & 1 & Guinea pig & 10,24 \\
\hline WIGA & Unclassified & WIGA $\left(=\right.$ ALLO $_{1}=$ ATCC 33217$)$ & 1 & Human & $1,7,10$ \\
\hline NY -23 & Unclassified & NY $-23\left(=\mathrm{ALLO}_{4}=\mathrm{ATCC} 33279\right)$ & 1 & $\begin{array}{l}\text { Environ- } \\
\text { mental }\end{array}$ & 7 \\
\hline MI-15 & Unclassified & MI-15 $\left(\mathrm{ALLO}_{2}\right)$ & 1 & Human & 7 \\
\hline EC-1 & E. coli & VAMC-EC1 & 2 & & \\
\hline
\end{tabular}

${ }^{a}$ 1, Center for Disease Control, Atlanta, Ga.; 2, VA Medical Center, Pittsburgh, Pa.; 3, A. W. Pasculle, Presbyterian-University Hospital, Pittsburgh, $\mathrm{Pa}$.; 4, Center for Disease Control, Atlanta, Ga., and VA Medical Center, Pittsburgh, $\mathrm{Pa}$.

${ }^{b}$ LDB, Legionnaires' disease bacterium.

Carbohydrate fermentation was performed in tubes of unbuffered BYEB containing $1.0 \%$ glucose, sucrose, maltose or lactose; $0.001 \%$ bromocresol purple was added as a pH indicator. API 20E (Analytabs, Plainview, N.Y.) was inoculated with a suspension of the organism in Mueller-Hinton broth (26) with a turbidity corresponding to a number $8 \mathrm{McFarland}$ standard. These were incubated in air with $2.5 \% \mathrm{CO}_{2}$ at $35^{\circ} \mathrm{C}$ and were examined at 3 and 5 days. The presence of brown pigment was determined after incubation for 5 days on charcoal-free buffered yeast extract agar with and without added tyrosine $(2.5 \mathrm{mM})$. To test for starch hydrolysis, the organisms were inoculated onto charcoal-free buffered yeast extract agar containing $0.15 \%$ soluble starch. After 5 days of incubation, the plates were flooded with Gram iodine solution. Starch hydrolysis resulted in clearing extending 3 to $4 \mathrm{~mm}$ beyond the area of growth.

Bromocresol purple spot test. One gram of bromocresol purple (Difco) was dissolved in $100 \mathrm{ml}$ of $1 \mathrm{~N} \mathrm{KOH}$. This solution was diluted with distilled water to a final concentration of $0.04 \%$. One drop of this solution was placed onto a piece of Whatman no. 1 filter paper, and a generous portion of growth from a BCYE agar culture was rubbed into the bromocresol purple-saturated area in a circular motion. "The color was recorded after $30 \mathrm{~s}$ of contact with the dye. A yellow to dull-green reaction was considered negative; a positive reaction was defined as the development of an aquamarine color.

Preparation of DNA. DNA was prepared by a modification of the method of Brenner et al. (3). Late log-phase bacteria were harvested by centrifugation and were resuspended in $40 \mathrm{ml}$ of phosphate-buffered saline $\left(\mathrm{Ca}^{2+}\right.$ - and $\mathrm{Mg}^{2+}$-free) containing $0.1 \mathrm{M}$ ethylenediaminetetracetic acid (EDTA). The bacteria were digested with proteinase $\mathrm{K}(80 \mu \mathrm{g} / \mathrm{ml})$ and $0.2 \%$ (wt/ vol) sodium dodecyl sulfate overnight at $37^{\circ} \mathrm{C}$. At that time, the sodium dodecyl sulfate concentration was increased to $1 \%(\mathrm{wt} / \mathrm{vol})$, and the temperature was raised to $65^{\circ} \mathrm{C}$; as a result, the suspension cleared. The lysed culture was then extracted with an equal volume of phenol-chloroform-isoamyl alcohol $(24: 24: 1)$ for 5 min with continuous shaking, and the phases were separated by centrifugation $(10,000 \times g$ for $10 \mathrm{~min})$. The aqueous phase was carefully removed, and the DNA was precipitated by the addition of 2 volumes (approximately $80 \mathrm{ml}$ ) of $95 \%$ ethanol. The DNA was allowed to dissolve overnight in $5 \mathrm{ml}$ of $0.1 \times \mathrm{SSC}$ (saline citrate, $1 \times$ is $0.15 \mathrm{M} \mathrm{NaCl}-0.015 \mathrm{M}$ trisodium citrate, $\mathrm{pH} 7.0$ ), after which it was digested sequentially with deoxyribonuclease-free ribonuclease $(50 \mu \mathrm{g}$ / $\mathrm{ml})$ for $30 \mathrm{~min}$ at $37^{\circ} \mathrm{C}$ and with proteinase $\mathrm{K}(40 \mu \mathrm{g} /$ $\mathrm{ml}$ ) for $2 \mathrm{~h}$. The DNA samples were re-extracted once with phenol-chloroform-isoamyl alcohol and twice with chloroform-isoamyl alcohol (24:1), after which the DNA was re-precipitated with ethanol. The precipitate was washed with 70 and $90 \%$ ethanol and was redissolved in $10 \mathrm{mM}$ tris(hydroxymethyl)aminomethane (Tris, pH 7.2 at $25^{\circ} \mathrm{C}$ )-1 mM EDTA.

Thermal denaturation studies. Samples of bacterial DNA, dissolved in $1 \times \mathrm{SSC}$, were adjusted to an absorbance of approximately 0.8 at $260 \mathrm{~nm}$. A solution of deoxyadenosine triphosphate was similarly prepared and served as a reference which allowed for the automatic correction of absorbance changes due to thermal expansion. Samples $(300 \mu \mathrm{l})$ were quickly brought to $78^{\circ} \mathrm{C}$ in tightly stoppered quartz cuvettes in a Gilford model 2000 recording spectrophotometer equipped with a model 2527 thermoprogrammer. The change in absorbance of each sample was followed as the temperature was increased at a rate of $0.5^{\circ} \mathrm{C} / \mathrm{min}$. The melting temperature $\left(T m_{e}\right)$ of each sample was calculated by using the equation of Marmur and Doty (15), with a corrected slope of $0.42{ }^{\circ} \mathrm{C} / 1 \%$ rise in guanine + cytosine $(\mathrm{G}+\mathrm{C})$ (based on our instrument calibration).

Preparation of radioactively labeled DNA. Bacterial DNA was labeled in vitro with $\left[\alpha-{ }^{32} \mathrm{P}\right] \mathrm{de}-$ oxycytosine triphosphate (specific activity, 500 to 750 $\mathrm{Ci} / \mathrm{mmol}$ ) by the nick translation method of Rigby et al. (22). Samples $(20 \mu \mathrm{l})$ of each DNA solution, diluted to 10 to $12 \mu \mathrm{g} / \mathrm{ml}$ in Tris-hydrochloride, $\mathrm{pH} 7.2\left(25^{\circ} \mathrm{C}\right)$, were added to a reaction mixture $(80 \mu \mathrm{l})$ containing 18 
$\mu \mathbf{M}$ deoxyadenosine triphosphate, deoxyguanosine triphosphate, and deoxythymidine triphosphate, and 1.8 $\mathbf{n M}\left[\alpha{ }^{32} \mathrm{P}\right]$ deoxycytosine triphosphate (specific activity, 500 to $750 \mathrm{Ci} / \mathrm{mmol}$ ) in translation buffer $(50 \mathrm{mM}$ of Tris-hydrochloride, $\mathrm{pH} 7.8,25^{\circ} \mathrm{C} ; 5 \mathrm{mM}$ of $\beta$-mercaptoethanol; and $50 \mu \mathrm{g}$ of nuclease-free bovine serum albumin per $\mathrm{ml}$ ). After incubation with activated deoxyribonuclease I (EC 3.1.4.5) (1 $\mathrm{ng} / 100-\mu$ l reaction) for $10 \mathrm{~min}$ at $15^{\circ} \mathrm{C}, E$. coli DNA polymerase I (EC 2.7.7.7) ( $2 \mathrm{U}$ ) was added, and incubation was continued for $75 \mathrm{~min}$ at $15^{\circ} \mathrm{C}$. Reactions were terminated by the addition of $10 \mu \mathrm{l}$ of $0.3 \mathrm{M}$ disodium EDTA ( $\mathrm{pH} \mathrm{8.0)}$. Labeled DNA was separated from unincorporated substrate by chromatography on a column of Sephadex $\mathrm{G}-50$ fine $(1$ by $15 \mathrm{~cm}$ ) equilibrated with $10 \mathrm{mM}$ Tris, $\mathrm{pH} 8.0\left(25^{\circ} \mathrm{C}\right)$. Probe DNA prepared in this manner had an average specific activity exceeding $8 \times 10^{7}$ $\mathrm{cpm} / \mu \mathrm{g}$ (nick translation reagents were obtained from Bethesda Research Laboratories, Rockville, Md.).

DNA reassociation. Heat-denatured bacterial DNA $(8 \mu \mathrm{g})$ prepared from each test strain was added to radioactive probe DNA $(0.29 \mathrm{ng})$ in $100 \mu \mathrm{l}$ of $0.28 \mathrm{M}$ PB (an equimolar amount of monobasic and dibasic sodium phosphate). Optimal conditions of reassociation were obtained by incubation of this mixture for $96 \mathrm{~h}$ at $64^{\circ} \mathrm{C}\left(T m_{e},-25^{\circ} \mathrm{C}\right.$ in $0.28 \mathrm{M} \mathrm{PB}$ for DNA containing $40 \% \mathrm{G}+\mathrm{C}$ ), at which time more than $85 \%$ of labeled input DNA had reannealled to homologous unlabeled DNA. To test for the presence of unpaired bases in hybridized segments, DNA reannealing was also performed at $75^{\circ} \mathrm{C}$ for selected combinations (2, 5). At $96 \mathrm{~h}$, single- and double-stranded DNAs were separated by a modification of the batch hydroxyapatite method of Brenner et al. $(3,4)$. Samples diluted to $0.12 \mathrm{M} \mathrm{PB}$ were added to $1.0 \mathrm{ml}$ of freshly prepared hydroxyapatite equilibrated in the same buffer at $65^{\circ} \mathrm{C}$. After vortical mixing, the samples were incubated at $65^{\circ} \mathrm{C}$ for $15 \mathrm{~min}$, at which time they were centrifuged at $1,000 \times g$ for $60 \mathrm{~s}$ in centrifuge carriers heated to $75^{\circ} \mathrm{C}$. The supernatant, containing singlestranded DNA, was decanted, and the hydroxyapatite pellets were resuspended in 3 volumes $(3.0 \mathrm{ml})$ of 0.12
$\mathrm{M} \mathrm{PB}$ and held at $65^{\circ} \mathrm{C}$ for $10 \mathrm{~min}$ with occasional mixing. This washing procedure was repeated six times. Double-stranded DNA was then eluted from hydroxyapatite by the addition of 3.0 volumes $(3.0 \mathrm{ml})$ of $0.4 \mathrm{M}$ PB followed by incubation in a boiling-water bath for $10 \mathrm{~min}$. After centrifugation, the supernatant was collected in scintillation vials and counted in an aqueous, xylene-Triton X-100-based liquid scintillation cocktail. Controls for self-reannealing of the labeled probe DNA were generally less than $5 \%$ of that observed in reactions containing an excess $(27,500 \times)$ of homologous unlabeled DNA, and these values were subtracted from all test samples.

The degree of relatedness between organisms is expressed as the amount of DNA bound to hydroxyapatite in heterologous reactions as compared with that observed in homologous reactions normalized to $100 \%$. Values represent averages of at least two experiments, each of which was done with duplicate reactions.

\section{RESULTS AND DISCUSSION}

The results of the DNA homology studies are presented in Table 2. With these data, the organisms tested can be separated into three groups. The isolates of L. pneumophila form one group, as previously reported (5), and show a high degree of sequence homology $(\geq 80 \%)$ between the individual strains. However, these three Legionella isolates show little or no homology to the other bacteria tested. These results are in agreement with previously published studies in which strains TATLOCK and WIGA were shown to be unrelated to $L$. pneumophila by DNA homology (10) and by serological techniques $(6,7)$.

The PPA strains and TATLOCK comprise a second group of bacteria which show a high degree $(>70 \%)$ of intergroup sequence homology at both $64^{\circ} \mathrm{C}$ and the more stringent tempera-

TABLE 2. Results of DNA relatedness studies

Source of
unlabeled
DNA

\footnotetext{
${ }^{a}$ Reannealing temperature.

${ }^{b}$ NT, Not tested.

'LDB, Legionnaires' disease bacterium.
} 
ture, $75^{\circ} \mathrm{C}$. This group appears to be unrelated to either L. pneumophila or to the other organisms tested. Previous studies have shown that PPA, TATLOCK, and another isolate (HEBA) are related antigenically and possess similar cellular fatty acid compositions, which are different from those of $L$. pneumophila and WIGA (10, 12).

WIGA, MI-15 and NY-23 have been grouped together as "atypical Legionella-like organisms" (ALLO) based upon their growth and morphological similarities to L. pneumophila (7). A differentiating feature is the intense, nondiffusible, blue-white fluorescence emitted by ALLO colonies grown on charcoal yeast extract agar (7). Direct fluorescent-antibody studies by Cordes et al. (7) suggest an immunological relationship between WIGA and MI-15; however, NY-23 did not cross-react. Our study shows that of these organisms, WIGA and MI-15 show a high degree $(>70 \%)$ of sequence homology at both temperatures, whereas NY-23 shows a low degree of homology to WIGA or MI-15 only at $64^{\circ} \mathrm{C}$, thereby defining at least two subgroups.

Although the presently unclassified strains TATLOCK, PPA, WIGA, MI-15, and NY-23 share many phenotypic characteristics with $L$. pneumophila, our hybridization studies point out significant differences in DNA homology between these organisms. It has been suggested that members of a species usually show $70 \%$ or greater sequence homology, and members of the same genus show 25 to $60 \%$ homology $(2,13)$. On the basis of these criteria, our data suggest that those organisms currently identified as TAT. LOCK and PPA are members of the same species and should be placed in a genus different from Legionella. Similarly, the DNA homology between WIGA and MI-15 suggests species level relatedness of these organisms.

Thermal denaturation studies support the proposed separation of these bacteria into three genera. L. pneumophila strains had a $T m_{e}$ of $85.6 \pm 0.4^{\circ} \mathrm{C}$, which corresponded to a mol\% $\mathrm{G}+\mathrm{C}$ of $38.8 \pm 0.9 \%(n=8)$. The DNAs of TATLOCK and the several PPA strains had $T m_{e}$ 's of $87.9 \pm 0.3^{\circ} \mathrm{C}$, corresponding to $44.3 \pm$ $0.7 \mathrm{~mol} \% \mathrm{G}+\mathrm{C}(n=9)$; and the ALLO strains tested had $T m_{e}$ 's of $86.4 \pm 0.3^{\circ} \mathrm{C}$, corresponding to $40.4 \pm 0.7 \mathrm{~mol} \% \mathrm{G}+\mathrm{C}(n=6)$. These differences are statistically significant by Student's $t$ test at the $P<0.01$ level.

Since submission of this manuscript, the names Legionella micdadei (11) and $L$. pittsburgensis (20) have been proposed for strains PPA and TATLOCK. We propose, based upon DNA homology, that L. micdadei Hebert et al., 1980 be transferred to a new genus, Tatlockia
(Tat.lock'i.a, M.L. gen. noun Tatlockia, of Tatlock; named for Hugh Tatlock, the individual who originally isolated this organism), as Tatlockia micdadei (Hebert et al., 1980) comb. nov. The type species of Tatlockia is T. micdadei, of which the type strain is strain TATLOCK (= American Type Culture Collection [ATCC] 33218). We believe that strains WIGA and MI15 belong to a new genus and species, for which we propose the names Fluoribacter (Flu.or.i.bac'ter, L.V. fluor, to flow, because of the fluorescence of this organism; M.L. masc. $n$. bacter, the masculine form of the Gr. neut. $n$. bactrum, a rod or staff; M.L. masc. n. Fluoribacter, fluorescent rod) and $F$. bozemanae (boze.man'ae, M.L. gen. noun bozemanae, of Bozeman, named for F. Marilyn Bozeman, who was of importance in the recognition of this group of organisms), respectively. F. Bozemanae is the type species of the genus, and strain WIGA (=ATTC 33217) is the type strain of the species. A name is not proposed for the NY-23 isolate, because further studies are required to elucidate its relationship to other members of this group.

Members of the family Legionellaceae produce colonies which are white to slightly grayish on BCYE agar. Occasionally, a faint pinkish or greenish sheen may be noted in confluent areas. After incubation for 5 days, $L$. pneumophila colonies become flatter with opaque centers and are slightly larger (2 to $4 \mathrm{~mm}$ ) than colonies of $T$. micdadei or $F$. bozemanae $(2$ to $3 \mathrm{~mm}$ ). In addition, Legionella colonies are sticky and tenaceous compared with the buttery consistency of colonies of Tatlockia or Fluoribacter. Two colony types have been described for Tatlockia: a slowly growing, white colony which develops protuberences. These protuberences on subculture give rise to the second, more rapidly growing, yellow-green colony type (20). Colonies of Fluoribacter fluoresce brightly when illuminated with longwave UV light. When examined with a dissecting microscope, colonies of all three species have a clear, glistening to gelatinous surface with an opaque, ground-glass interior. On BCYE agar containing $0.001 \%$ bromocresol purple and $0.001 \%$ bromothymol blue, Legionella colonies are white to pale green, Fluoribacter colonies are a brighter green, and Tatlockia colonies are blue-gray (Vickers, Brown, and Garrity, submitted for publication). Although growth of these organisms is best on BCYE agar, adapted growth, although poor, may be occasionally obtained on a variety of nutritionally complex, charcoal-free media. However, growth has not been observed on unsupplemented sheep blood agar.

All members of this family are slender, pale, 
TABLE 3. Phenotypic differentiation of species

\begin{tabular}{|c|c|c|c|}
\hline Character & L. pneumophila & T. micdade $i$ & F. bozemanae \\
\hline Color on dye-containing agar ${ }^{a}$ & White-green & Blue-gray & Green \\
\hline \multicolumn{4}{|l|}{ Brown pigment production: } \\
\hline No added tyrosine & \pm & - & - \\
\hline With added tyrosine & + & - & + \\
\hline Catalase $^{b}$ & + & ++ & ++ \\
\hline Oxidase $^{c}$ & + & \pm & - \\
\hline Starch hydrolysis & + & $\overline{-}$ & + \\
\hline Gelatinase & + & - & + \\
\hline Colony fluorescence & - & - & + \\
\hline Bromocresol purple spot test & - & + & - \\
\hline
\end{tabular}

${ }^{a}$ BCYE agar with $0.001 \%$ bromothymol blue and $0.001 \%$ bromocresol purple.

${ }^{b}++$, Immediate effervescence; + , effervescence after $10 \mathrm{~s}$.

" + , Dark blue in $<60 \mathrm{~s} ; \pm$, dark blue in $>60 \mathrm{~s}$.

gram-negative rods ( 4 to $5 \mu \mathrm{m}$ by $0.5-0.7 \mu \mathrm{m}$ ) with blunt to slightly rounded ends. Tatlockia and Fluoribacter occasionally have tapered ends and may be slightly curved, with short filaments, to about $25 \mu \mathrm{m}$. Legionella cells are more pleomorphic and tend to form long, vine-like filaments in culture. From tissues, Tatlockia may be partly acid-fast (20). Although motility of some strains has been reported (10) and polar flagella have been demonstrated $(10,12,20)$, these organisms are usually nonmotile after agar passage. Motility of some strains may be restored by passage on semisolid media.

Although growth occurs, no gas or acid production can be demonstrated in charcoal-free, unbuffered yeast extract broth containing glucose, maltose, lactose, or sucrose. All of these organisms are nitrate negative. L. pneumophila produces a poorly diffusible, brown pigment on charcoal-free yeast extract agar, whereas $F$. bozemanae produces visible pigmentation only if the medium is supplemented with $2.5 \mathrm{mM}$ tyrosine. On this medium, all L. pneumophila strains produce pigment. $T$. micdadei produces no pigment on either medium. L. pneumophila and $F$. bozemanae are gelatinase positive and hydrolyze starch; $T$. micdadei is negative for these activities. No other biochemical reactivity could be detected by the API 20E. Table 3 shows those characteristics which may be used to differentiate $T$. micdadei, $F$. bozemanae, and $L$. pneumophila.

Until further data are available, it is appropriate to include these organisms in the family Legionellaceae because of their phenotypic similarities.

\section{ACKNOWLEDGMENTS}

This work was supported by the Medical Research Service of the Veterans Administration.

We thank Monto Ho, John Armstrong, and Victor Yu for critical review of the manuscript, and A. W. Pasculle for providing some of the strains used in this study. We also thank Donna Williams for excellent secretarial assistance. Elaine Elder's maintenance and quality control of stock cultures were essential to the conduct of this study.

\section{REPRINT REQUESTS}

Address reprint requests to: Arnold Brown, M.D., Chief, Infectious Disease Section, VA Medical Center, University Drive C, Pittsburgh, PA 15240.

\section{LITERATURE CITED}

I. Bozeman, F. M., J. W. Humphries, and J. M. Campbell. 1968. A new group of rickettsia-like agents recovered from guinea pigs. Acta Virol. 12:87-93.

2. Brenner, D. J. 1973. Deoxyribonucleic acid reassociation in the taxonomy of enteric bacteria. Int. J. Syst. Bacteriol. 23:298-307.

3. Brenner, D. J., G. R. Fanning, K. E. Johnson, R. V. Citarella, and S. Falkow. 1969. Polynucleotide sequence relationships among members of Enterobacte. riaceae. J. Bacteriol. 98:637-650.

4. Brenner, D. J., G. R. Fanning, A. V. Rake, and K. E. Johnson. 1969. Batch procedures for thermal elution of DNA from hydroxyapatite. Anal. Biochem. 28:447459.

5. Brenner, D. J., A. G. Steigerwalt, and J. E. MeDade. 1979. Classification of the Legionnaires' disease bacterium: Legionella pneumophila, genus novum, species nova, of the Family Legionellaceae, familia nova. Ann. Intern Med. 90:656-658.

6. Cherry, W. B., and R. M. McKinney. 1979. Detection of Legionnaires' disease bacteria in clinical specimens by direct immunofluorescence, p. 92-103. In G. L. Jones and G. A. Hébert (ed.), Legionnaires': the disease, the bacterium, and methodology. Center for Disease Control, Atlanta.

7. Cordes, L. B., H. W. Wilkinson, G. W. Gorman, B. J. Fikes, and D. W. Fraser. 1979. Atypical LegionellaLike organisms: fastidious water-associated bacteria pathogenic for man. Lancet ii:927-930.

8. Feely, J. C., G. C. Gorman, R. E. Weaver, D. C. Mackel, and H. W. Smith. 1978. Primary isolation media for the Legionnaires' disease bacterium. J. Clin. Microbiol. 8:320-325.

9. Fraser, D. W., T. R. Tsai, W. Orenstein, W. E. Parkin, H. J. Beecham, R. G. Sharrar, J. Harris, G. F. Mallison, S. M. Martin, J. E. McDade, C. C. Shepard, P. S. Brachman, and the Field Investigation Team. 1977. Legionnaires' disease: description of an epidemic of pneumonia. N. Engl. J. Med. 297:11971203. 
10. Hebert, G. A., C. W. Moss, L. K. McDougal, F. M. Bozeman, R. M. McKinney, and D. J. Brenner. 1980. The rickettsia-like organisms TATLOCK (1943) and HEBA (1959): bacteria phenotypically similar, but genetically distinct from Legionella pneumophila and the WIGA bacterium. Ann. Intern. Med. 92:45-52.

11. Hebert, G. A., A. G. Steigerwalt, and D. J. Brenner. 1980. Legionella micdadei species nova: classification of a third species of Legionella associated with human pneumonia. Curr. Microbiol. 3:225-257.

12. Hebert, G. A., B. M. Thomason, P. P. Harris, M. D. Hicklin, and R. M. McKinney. 1980. "Pittsburgh Pneumonia Agent": a bacterium phenotypically similar to Legionella pneumophila and identical to the TATLOCK bacterium. Ann. Intern. Med. 92:53-54.

13. Isenberg, H. D. 1979. Microbiology of Legionnaires' disease bacterium. Ann. Intern. Med. 90:502-505.

14. Lewallen, K. R., R. M. McKinney, D. J. Brenner, C. W. Moss, D. H. Dail, B. M. Thomason, and R. A Bright. 1979. A newly identified bacterium phenotypi cally resembling, but genetically distinct from, Legionella pneumophila: an isolate in a case of pneumonia. Ann. Intern. Med. 91:831-834.

15. Marmur, J., and P. Doty. 1962. Determination of the base composition of deoxyribonucleic acid from its thermal denaturation temperature. J. Mol. Biol. 5:109-118.

16. McDade, J. E., D. J. Brenner, and F. M. Bozeman. 1970. Legionnaires' disease bacterium isolated in 1947. Ann. Intern. Med. 90:659-661.

17. McDade, J. E., C. C. Shepard, D. W. Fraser, T. R. Tsai, M. A. Redus, W. R. Dowdee, and Laboratory Investigation Team. 1977. Legionnaires' disease: isolation of a bacterium and demonstration of its role in other respiratory disease. N. Engl. J. Med. 297:11971203.
18. Moss, C. W., and S. B. Dees. 1979. Cellular fatty acid composition of WIGA: a rickettsia-like agent similar to the Legionnaires' disease bacterium. J. Clin. Microbiol. 10:390-391.

19. Moss, C. W., R. E. Weaver, S. B. Dees, and W. B. Cherry. 1977. Cellular fatty acid composition of isolates from Legionnaires' disease. J. Clin. Microbiol. 6:140143.

20. Pasculle, A. W., J. C. Feely, R. J. Gibson, L. G. Cordes, R. L. Myerowitz, C. M. Patton, G. W. Gorman, C. L. Carmack, J. W. Ezzell, and J. N. Dowling. 1980. Pittsburgh Pneumonia Agent: direct isolation from human lung tissue. J. Infect. Dis. 141:727-732.

21. Pasculle, A. W., R. L. Myerowitz, and C. R. Rinaldo. 1979. New bacterial agent of pneumonia isolated from renal-transplant recipients. Lancet ii:58-61.

22. Rigby, P. W. J., M. Dieckman, C. Rhodes, and P. Berg. 1977. Labeling deoxyribonucleic acid to high specific activity in vitro by nick translation with DNA Polymerase I. J. Mol. Biol. 113:237-25I

23. Ristroph, J. D., K. W. Hedlund, and R. G. Allen. 1980. Liquid medium for growth of Legionella pneumophila. J. Clin. Microbiol. 11:19-21.

24. Tatlock, H. 1944. A rickettsia-like organism recovered from guinea pigs. Proc. Soc. Exp. Biol. Med. 57:95-99.

25. Thomason, G. M., P. P. Harris, M. D. Hicklin, J. A. Blackmon, C. W. Moss, and F. Matthews. 1979. Detection of a Legionella-like bacterium related to WIGA in a fatal case of pneumonia. Ann. Intern. Med. 91:673-676.

26. Weaver, R. E., and J. C. Feely. 1979. Cultural and biochemical characterization of the Legionnaires' disease bacterium, p. 20-25. In G. L. Jones and G. A. Hébert (ed.), Legionnaires': The disease, the bacterium, and methodology. Center for Disease Control, Atlanta. 